\title{
Effect of citric acid supplemented diets on aflatoxin degradation, growth performance and serum parameters in broiler chickens"
}

\author{
Efecto de dietas suplementadas con ácido cítrico en la degradación de aflatoxinas, \\ el crecimiento y los parámetros sanguíneos de pollos de engorda
}

\author{
L Salgado-Tránsito, JC Del Río-García, JL Arjona-Román, E Moreno-Martínez, A Méndez-Albores* \\ Facultad de Estudios Superiores, Universidad Nacional Autónoma de México, UNIGRAS-Unidad de Investigación \\ Multidisciplinaria, Cuautitlán Izcalli, México.
}

\begin{abstract}
RESUMEN
Este estudio fue realizado para investigar los efectos del ácido cítrico (CA) sobre la degradación de las aflatoxinas, el crecimiento y algunos componentes del suero sanguíneo de pollos de engorda. 300 pollos de un día de edad (Ross) fueron divididos aleatoriamente en cinco grupos con tres repeticiones de 20 pollos cada uno. Cuatro grupos recibieron la dieta suplementada con CA $(6,25,12,5,25$ y $50 \mathrm{~g} / \mathrm{kg})$, mientras que el otro sirvió como grupo control. La dieta fue preparada con base en las recomendaciones de la NRC, y el experimento fue terminado cuando las aves alcanzaron 28 días de edad. Los resultados mostraron que las aflatoxinas en la dieta a una concentración de $39 \mathrm{ng} / \mathrm{g}$ fueron degradadas (92\%) por el procedimiento de acidificación. En general, el peso vivo (LBW) fue ligeramente mayor en los animales alimentados con la adición de CA; la dieta con la concentración más alta $(50 \mathrm{~g} \mathrm{CA} / \mathrm{kg})$ resultó en un aumento significativo en el LBW y una mejora en el índice de conversión. Sin embargo, a medida que se incrementó la concentración de CA, valores altos en la actividad de la enzima aspartato aminotransferasa fueron registrados. Por el contrario, el hematocrito, las proteínas totales y la albúmina no fueron afectados por cualquier nivel de inclusión de CA en la dieta. De estos resultados, se concluye que el CA puede ser usado como un aditivo para degradar a las aflatoxinas en la dieta, así como para promover el crecimiento en pollos de engorda jóvenes.
\end{abstract}

Key words: broilers, aflatoxins, citric acid, serum parameters.

Palabras clave: pollos de engorda, aflatoxinas, ácido cítrico, parámetros sanguíneos.

\section{INTRODUCTION}

The poultry industry is continuously searching for additives to improve feed efficiency and animal health; among these compounds, organic acids are promising alternatives. Dietary organic acids and their salts inhibit microorganism growth in feed, and maintain the microbial balance in the gastrointestinal tract (GIT) (Naidu 2000). Several authors have reported positive effects of certain organic acids in poultry diets (Runho et al 1997, Jin et al 1998), since acidifiers might improve poultry performance by reducing colonization of pathogenic microorganisms and toxic bacterial metabolites such as ammonia and amines (Chaveerach et al 2004). Moreover, MéndezAlbores et al (2007) have observed that citric acid degrades aflatoxins in the ration.

Aflatoxins (AF) are a group of acutely toxic metabolites produced by toxigenic strains of Aspergillus flavus Link, Aspergillus parasiticus Speare, and Aspergillus nomius Kurtzman et al (Feibelman et al 1998, Weidenbörner 2007). These toxins have closely similar structures and

\footnotetext{
Accepted: 19.01.2011.

\# CONACYT project No 117893.

* Cuautitlán Izcalli, C.P. 54714, México; albores@unam.mx
}

form a unique group of highly oxygenated, naturally occurring heterocyclic compounds. Four principal AF are produced by those fungi: $\mathrm{AFB}_{1}, \mathrm{AFB}_{2}, \mathrm{AFG}_{1}$, and $\mathrm{AFG}_{2}$. AF causes a wide range of clinical and subclinical problems in poultry related to many different toxic effects; among them, reduced performance, hepatic intoxication, adverse effects on carcass as well as on egg shell quality, immunosuppression, and carcinogenicity have been reported by different authors (Charmley et al 1995, Hussein and Brasel 2001, Kermanshahi et al 2007).

At present, unfortunately, aflatoxins are considered unavoidable contaminants of feed and foods. The Food and Agriculture Organization (FAO) estimates that at least $25 \%$ of world cereal production is contaminated with mycotoxins (Dowling 1997). For this reason, developments of detoxification procedures are needed. Such detoxification procedures should not only reduce the concentration of toxins to "safe" levels (below regulatory limits), but also to prevent production of new toxic products derived from the aflatoxin degradation, and of course non-reduction of the nutritional value of the treated commodities. A number of methods have been investigated in connection with their effectiveness to inactivate aflatoxins in contaminated feedstuffs; the aims of these methods are either to remove or to destroy the toxin, and can be classified into physical, biological and chemical methods. 
Citric acid (CA) is one of the most widely-used food additives, which is commonly used as a preservative, acidulant, $\mathrm{pH}$ control agent, flavor enhancer, and antioxidant in many foods. Global production (mainly through microbiological fermentation) is estimated to be approaching $4^{5}$ tons per year (Kristiensen et al 1999). The US Food and Drug Administration classify CA as a GRAS (Generally Recognised as Safe) substance. ${ }^{1}$ However, some toxic effects of CA have been also studied (Aktaç et al 2003 ${ }^{\mathrm{a}}, 2003^{\mathrm{b}}$, Y1lmaz et al 2008, Abd-AlGadir et al 2009).

Our recent studies indicated that aqueous CA had a detoxification effect when used to treat aflatoxincontaminated feeds (Méndez-Albores et al 2009). Considering that the acidic treatment protects ducklings from chronic aflatoxin toxicity and greatly reduces the mutagenic and carcinogenic activity of aflatoxins in the Ames test (Méndez-Albores et al 2005), the purpose of the present study was to determine the effect of dietary CA on the stability of B-aflatoxins in feed, as well as on growth performance and biochemical parameters in the blood of young broiler chickens.

\section{MATERIAL AND METHODS}

\section{CHEMICALS}

Anhydrous citric acid (99.9\% purity) was obtained from Mallinckrodt Baker (JT Baker, Xalostoc, Mexico). The chemical properties of citric acid are as follows: chemical formula $\mathrm{C}_{6} \mathrm{H}_{8} \mathrm{O}_{7}$, and molecule weight 192.13 $\mathrm{g} / \mathrm{mol}$. All other chemicals used were analytical reagent grade.

DIETS

A control sorghum-soybean meal based diet was prepared based on National Research Council (NRC 1994) recommendations. The composition and chemical analysis is presented in table 1. For preparing other treatments, the control diet was supplemented with aqueous CA at levels of $6.25,12.5,25$ and $50 \mathrm{~g} / \mathrm{kg}$, respectively. No antibiotic or anticoccidial drug was used in those diets. The moisture content (M.C.) of the diets was adjusted to $30 \%$ by adding $265 \mathrm{ml} / \mathrm{kg}$ of aqueous CA solutions. Samples were mixed at low speed for $15 \mathrm{~min}$ in a mixer (model C-100, Hobart Corp., Troy, OH). After mixing, samples were transferred to plastic bags and stored at $4^{\circ} \mathrm{C}$ for $72 \mathrm{~h}$, in order to achieve M.C. equilibration. The acid-treated feed was dried in a vacuum oven at $40^{\circ} \mathrm{C}$ for $48 \mathrm{~h}$, and thoroughly mixed. The final average M.C. of the diets was $12 \%$, determined by drying replicate portions of 5-10 g each of feed at $103{ }^{\circ} \mathrm{C}$ for $72 \mathrm{~h}$, with percentages calculated on a wet-weight basis. The control diet (non CA added) was treated similarly to the CA treated diets regarding M.C. adjustment, mixing, equilibration and drying. The chicks were fed with five diets: (1) CAsupplemented feed with $6.25 \mathrm{~g} / \mathrm{kg}$; (2) CA-supplemented feed with $12.5 \mathrm{~g} / \mathrm{kg}$; (3) CA-supplemented feed with 25 $\mathrm{g} / \mathrm{kg}$; (4) CA-supplemented feed with $50 \mathrm{~g} / \mathrm{kg}$ citric acid; and (5) the control diet, consisting of CA-free feed. The $\mathrm{pH}$ of the diets was determined according to the 02-52 AACC method (AACC 2000). All diets were tested for total aflatoxins before and after $\mathrm{CA}$ addition.

\section{AFLATOXIN ANALYSIS}

The total aflatoxin content in the feed was determined according to the 991.31 AOAC (1995) method using monoclonal antibody columns for aflatoxins B1 and B2 (VICAM Science Technology, Watertown, MA, USA). The detection limit for aflatoxins with the immunoaffinity column (IAC) via fluorescence measurement is approximately $0.5 \mathrm{ng} / \mathrm{g}$ (Hansen 1990). Aflatoxin identification was performed by a modification of the HPLC-AFLATEST procedure. A Waters HPLC equipment with two pumps (Model 510. Waters Associates, Milford, MA), and a Waters nova-pak C18 reverse phase column ( $5 \mu \mathrm{m}, 3.9 \mathrm{~mm} 150 \mathrm{~mm})$ was used.

Table 1. Ingredients and nutrient composition of the control experimental diet.

Ingredientes y composición de nutrientes de la dieta control experimental.

\begin{tabular}{|c|c|c|c|}
\hline Ingredient & $\%$ & Calculated analysis ${ }^{4}$ & $\%$ \\
\hline Sorghum & 50.33 & $\mathrm{ME}(\mathrm{Kcal} / \mathrm{Kg})^{5}$ & 3010 \\
\hline Soybean meal (48) & 41.52 & Crude protein & 24 \\
\hline Sunflower oil & 3.46 & Calcium & 1 \\
\hline Orthofosfate & 1.86 & Phosphorus, total & 0.5 \\
\hline Calcium carbonate & 1.56 & Methionine + Cystine & 1.6 \\
\hline Salt $(\mathrm{NaCl})$ & 0.41 & Lysine & 1.5 \\
\hline Alimet $88^{1}$ & 0.35 & Threonine & 0.97 \\
\hline L-Lisine $\mathrm{HCl}$ & 0.19 & Zinc (mg/kg) & 45 \\
\hline Choline chloride & 0.1 & Analyzed & \\
\hline Vitamine premix ${ }^{2}$ & 0.1 & Crude protein & 23.75 \\
\hline Mineral premix ${ }^{3}$ & 0.05 & Calcium & 1.1 \\
\hline Sugar + zinc & 0.05 & Phosphorus, total & 0.57 \\
\hline L-Threonine & 0.03 & & \\
\hline
\end{tabular}

1 Aqueous solution of 2-hydroxy-4-(methylthio) butanoic acid(HMTBA).

2 Vitamine premix supplied/kg diet: Vitamin A, 12000 IU; Vitamin D3, 2500 IU; Vitamin E, 15 mg; Vitamin K3, 2mg; Vitamin B1, 2.25mg; Vitamin B2, $7.5 \mathrm{mg}$; Vitamin B6, 3.5mg; Vitamin B12, $0.020 \mathrm{mg}$; folic acid, $1.5 \mathrm{mg}$; pantothenic acid, $12.5 \mathrm{mg}$.

3 Mineral premix supplied/kg diet: $\mathrm{Cu}, 8 \mathrm{mg}$ as $\mathrm{CuSO} 4.5 \mathrm{H} 2 \mathrm{O} ; \mathrm{Mn}$, $100 \mathrm{mg}$ as $\mathrm{MnO} ; \mathrm{Fe}, 80 \mathrm{mg}$ as FeSO4.H2O; I, $1 \mathrm{mg}$ as ethylenediamine dihydroiodide (EDDI); Se, $0.15 \mathrm{mg}$ as $\mathrm{Na} 2 \mathrm{SeO} 3$.

4 Data on dry matter.

5 ME: Metabolisable energy. 
Standards as well as samples collected from the IAC ( 20 $\mu \mathrm{l})$, were injected into a HPLC and eluted isocratically with a mobile phase of $12.5 \mathrm{mN}$ acetic acid:acetonitrile $(1: 1, \mathrm{v} / \mathrm{v}, \mathrm{pH}=3.5)$ at a flow rate of $1 \mathrm{ml} / \mathrm{min}$. Aflatoxins were fluorometrically detected and identified using a fluorescence detector (Waters model 470); the excitation and emission wavelengths were 338 and $425 \mathrm{~nm}$, respectively. Aflatoxins (standards and samples), were analyzed by HPLC without derivatization. Aflatoxins were identified by their retention time (Rt), compared with those for a pure aflatoxin standard solution under identical conditions.

\section{ANIMALS}

For the experiment, 300 one-day-old Ross broiler chicks were divided into four experimental groups and one reference group (such that the average weight of the animals in the groups differed by less than $1 \mathrm{~g}$ ). Twenty birds of mixed sex (three replicates) were housed in plastic cages, $113 \mathrm{~cm}$ (l) $90 \mathrm{~cm}$ (w) $60 \mathrm{~cm} \mathrm{(h),} \mathrm{in} \mathrm{a}$ light-cycled room ( $12 \mathrm{~h}$ cycle), maintained within the temperature range of $30-32^{\circ} \mathrm{C}$ with free access to food and water. In each cage, local heat sources from IR lamps of $250 \mathrm{~W}$ were used to maintain the body temperature of the birds between 39 and $42{ }^{\circ} \mathrm{C}$. The floor was covered with $5 \mathrm{~cm}$ deep wood shavings and two $2 \mathrm{~L}$ capacity chick cup drinkers were placed per cage. When birds were 14 days old, the cup drinkers were replaced by trough drinkers. During the first seven days of age, chicks were fed in a tray feeder, over which a $1 \mathrm{~cm}$ mesh plastic screen was placed to prevent feed wastage. After seven days of age, feed was offered in trough feeders $91.5 \mathrm{~cm}$ (l) $11.5 \mathrm{~cm} \mathrm{(w)} 5.4 \mathrm{~cm}(\mathrm{~d})$.

\section{COLLECTION OF SAMPLES AND MEASUREMENTS}

Feed and water were provided ad libitum during the whole period of the experiment ( $28 \mathrm{~d})$. Broilers were individually weighed at the beginning of the experiment, then at weekly intervals until the end of the experiment. Live body weight (LBW), feed consumption (FC), and feed conversion ratio (FCR) were recorded during these periods. After 28 days, blood was drawn by cardiac puncture under anesthesia (the bird was exposed for one minute to $40 \%$ carbon dioxide, $30 \%$ oxygen, and $30 \%$ nitrogen) from 15 randomly selected birds from each treatment, and serum prepared. Total protein and albumin were determined using commercially available kits (Wiener Lab, Rosario Argentina). The serum alanine aminotransferase (ALT) and aspartate aminotransferase (AST) activities were determined according to Reitman and Franked (1970). The bled animals were then exposed to $80 \%$ carbon dioxide, $5 \%$ oxygen, and $15 \%$ nitrogen for euthanasia (Coenen et al 2000). Proventriculus, gizzard, liver plus gall bladder, spleen and bursa were excised, washed in cold saline and their relative percentages estimated. The intestinal weight was also considered and $\mathrm{pH}$ values in different parts of the GIT (proventriculus, gizzard, duodenum, jejunum and ileum) were also registered immediately by using a digital $\mathrm{pH}$ meter (HANNA, model HI 99163, Romania).

\section{EXPERIMENTAL DESIGN AND STATISTICAL ANALYSIS}

The experiment was conducted as a completely randomized design with three replicates. Data were assessed by analysis of variance (ANOVA) and means were separated by the Dunnet procedure using the Statistical Analysis System (SAS 1998). A significance value of $(=0.05)$ was used to distinguish significant differences between treatments.

\section{RESULTS}

Table 2 shows the result of the aflatoxin analysis. Results showed that feed contained $39 \pm 0.8 \mathrm{ng} / \mathrm{g}$ of total aflatoxins. However, in the CA supplemented diets, the

Table 2. Efficiency of aflatoxin degradation of aqueous citric acid and $\mathrm{pH}$ in the diet.

Eficiencia del ácido cítrico acuoso en la degradación de las aflatoxinas y valores de $\mathrm{pH}$ de la dieta.

\begin{tabular}{|c|c|c|c|c|}
\hline \multirow{2}{*}{$(\mathrm{g} \mathrm{CA} / \mathrm{kg})$} & \multicolumn{2}{|c|}{ Total aflatoxins (ng/g)* } & \multirow{2}{*}{$\begin{array}{c}\text { Disappearance } \\
\text { of fluorescence }(\%)\end{array}$} & \multirow{2}{*}{$\begin{array}{l}\text { Final } \mathrm{pH} \\
\text { of diet }\end{array}$} \\
\hline & Before $\mathrm{CA}$ addition & After $\mathrm{CA}$ addition & & \\
\hline 6.25 & $40 \pm 1.5^{\mathrm{a}}$ & $4 \pm 0.7^{\mathrm{a}}$ & 90 & $5.6 \pm 3.4^{-4 a}$ \\
\hline 12.5 & $37 \pm 1.2^{\mathrm{a}}$ & $3 \pm 0.6^{\mathrm{a}}$ & 92 & $5.1 \pm 4.3^{-4 \mathrm{~b}}$ \\
\hline 25 & $42 \pm 1.9^{\mathrm{a}}$ & $3 \pm 0.9^{\mathrm{a}}$ & 93 & $4.5 \pm 6.3^{-4 c}$ \\
\hline 50 & $38 \pm 0.7^{\mathrm{a}}$ & $3 \pm 0.3^{\mathrm{a}}$ & 92 & $3.9 \pm 3.6^{-4 d}$ \\
\hline 0 & $39 \pm 0.4^{\mathrm{a}}$ & $42 \pm 2.6^{b}$ & - & $6.2 \pm 4.2^{-4 \mathrm{e}}$ \\
\hline
\end{tabular}

Mean of three replicates \pm s.e.

Column means with common superscripts do not differ $(\mathrm{P}>0.05)$.

* AFB1 and AFB2. 
post-reaction aflatoxin content was $3 \pm 0.3 \mathrm{ng} / \mathrm{g}$. This reduction in the aflatoxin content represents approximately 92\%. The chromatograms of the HPLC (not presented) indicate that the toxins in the feed were $\mathrm{AFB}_{2}$ and $\mathrm{AFB}_{1}$, with concentrations of 3 and $36 \mathrm{ng} / \mathrm{g}$, respectively. In extracts of CA-supplemented diets, the fluorescence of $\mathrm{AFB}_{2}$ was not detected, while $\mathrm{AFB}_{1}$ fluorescence was much weaker than in the untreated samples. Table 2 also shows the $\mathrm{pH}$ values for the ration; as the CA concentration increased, the $\mathrm{pH}$ value was decreased. Samples with no acid presented an average $\mathrm{pH}$ value of 6.2; while the lowest $\mathrm{pH}$ value (3.9) was observed in the ration prepared with the addition of $50 \mathrm{~g} \mathrm{CA} / \mathrm{kg}$.

The effects of dietary CA supplementation on growth performance of broiler chickens are summarized in table 3 . The results indicated that LBW was significantly improved in birds fed diet supplemented with 12.5, 25 and $50 \mathrm{~g} \mathrm{CA} / \mathrm{kg}$, with average values of 913,892 and $1013 \mathrm{~g}$, respectively. In general, LBW was slightly higher in animals fed with the addition of CA in their diet, as compared to the control. Additionally, FC did not significantly differ between groups; the average value was $57 \mathrm{~g} / \mathrm{bird} /$ day. Birds fed supplemental CA had significantly better FCR values compared to the control diet $(1.99 \mathrm{~g}$ feed/g gain). However, no difference was found in birds fed with the addition of $6.25,12.5$ and $25 \mathrm{CA} / \mathrm{kg}$; in those groups FCR values were 1.81, 1.81 and $1.82 \mathrm{~g}$ feed/g gain, respectively. The lowest value in FCR was registered in birds fed a diet containing $50 \mathrm{~g} \mathrm{CA} / \mathrm{kg}$ ( $1.55 \mathrm{~g}$ feed/g gain).

Dietary supplementation of CA did not significantly affect the values of hematocrite and the serum concentrations of total protein and albumin (table 4). However, significant differences were found for both serum AST and ALT activities levels. As the CA concentration increased, higher AST values were registered. The animals fed diet supplemented with $50 \mathrm{~g} \mathrm{CA} / \mathrm{kg}$, presented the highest AST value (45 U/L), as compared to the control ( $23 \mathrm{U} / \mathrm{L})$. On the contrary, supplementation of CA lowered the values of the ALT activity.

Organ weights were not affected due to the addition of $\mathrm{CA}$ to the ration (table 5). Moreover, the effect of dietary acidification on $\mathrm{pH}$ values of different GIT segments are presented in table 6 . The results indicated that CA supplementation had no effect on the proventriculus, gizzard, duodenum, jejunum and ileum $\mathrm{pH}$ values.

\section{DISCUSSION}

Sorghum is considered the fifth most important crop in the world after wheat, rice, maize, and barley, due to its resistance to drought and high temperatures (ICRISAT/FAO 1996). Its nutritional value is quite similar to maize and it has been used as an ingredient for inclusion in foods and feeds. Unfortunately, sorghum

Table 3. Effect of dietary citric acid on growth performance of broiler chickens.

Efecto del ácido cítrico sobre el desempeño del pollo de engorda.

\begin{tabular}{lccccc}
\hline \multirow{2}{*}{ Parameter } & \multicolumn{5}{c}{ Dietary organic acid supplementation $(\mathrm{g} \mathrm{CA} / \mathrm{kg})$} \\
\cline { 2 - 6 } & 6.25 & 12.5 & 25 & 50 & $0(\mathrm{control})$ \\
\hline LBW $(\mathrm{g})$ & $851 \pm 13.6^{\mathrm{ab}}$ & $913 \pm 15.4^{\mathrm{bc}}$ & $892 \pm 15.5^{\mathrm{bc}}$ & $1013 \pm 47.8^{\mathrm{c}}$ & $786 \pm 11.4^{\mathrm{a}}$ \\
FC (g/bird/day) & $55 \pm 2.3^{\mathrm{a}}$ & $59 \pm 2.7^{\mathrm{a}}$ & $58 \pm 2.9^{\mathrm{a}}$ & $56 \pm 3.8^{\mathrm{a}}$ & $56 \pm 2.0^{\mathrm{a}}$ \\
FCR (g feed/g gain) & $1.81 \pm 0.02^{\mathrm{b}}$ & $1.81 \pm 0.02^{\mathrm{b}}$ & $1.82 \pm 0.02^{\mathrm{b}}$ & $1.55 \pm 0.03^{\mathrm{c}}$ & $1.99 \pm 0.02^{\mathrm{a}}$ \\
\hline
\end{tabular}

Mean \pm s.e.

Row means with common superscripts do not differ $(\mathrm{P}>0.05)$.

$\mathrm{LBW}=$ live body weight; $\mathrm{FC}=$ feed consumption; $\mathrm{FCR}=$ feed conversion ratio.

$\mathrm{n}=60$.

Table 4. Effect of dietary citric acid on some serum constituents in broiler chickens.

Efecto del ácido cítrico sobre algunos constituyentes del suero sanguíneo de los pollos de engorda.

\begin{tabular}{lccccc}
\hline \multirow{2}{*}{ Parameter } & \multicolumn{4}{c}{ Dietary organic acid supplementation $(\mathrm{g} \mathrm{CA} / \mathrm{kg})$} \\
\cline { 2 - 6 } & 6.25 & 12.5 & 25 & 50 & $0(\mathrm{control})$ \\
\hline Hematocrite (\%) & $63 \pm 1.7^{\mathrm{a}}$ & $67 \pm 1.2^{\mathrm{a}}$ & $67 \pm 2.7^{\mathrm{a}}$ & $66 \pm 1.0^{\mathrm{a}}$ & $63 \pm 1.8^{\mathrm{a}}$ \\
Total protein (g/L) & $3.8 \pm 0.1^{\mathrm{a}}$ & $3.6 \pm 0.1^{\mathrm{a}}$ & $3.6 \pm 0.1^{\mathrm{a}}$ & $3.6 \pm 0.1^{\mathrm{a}}$ & $3.6 \pm 0.1^{\mathrm{a}}$ \\
Albumin (g/L) & $1.1 \pm 0.1^{\mathrm{a}}$ & $1.2 \pm 0.1^{\mathrm{a}}$ & $1.3 \pm 0.1^{\mathrm{a}}$ & $1.2 \pm 0.1^{\mathrm{a}}$ & $1.2 \pm 0.1^{\mathrm{a}}$ \\
AST (U/L) & $30 \pm 0.9^{\mathrm{b}}$ & $32 \pm 1.0^{\mathrm{b}}$ & $38 \pm 1.2^{\mathrm{c}}$ & $45 \pm 0.8^{\mathrm{d}}$ & $23 \pm 1.7^{\mathrm{a}}$ \\
ALT (U/L) & $5 \pm 0.3^{\mathrm{b}}$ & $6 \pm 0.9^{\mathrm{b}}$ & $6 \pm 1.3^{\mathrm{b}}$ & $8 \pm 0.3^{\mathrm{b}}$ & $21 \pm 0.8^{\mathrm{a}}$ \\
\hline
\end{tabular}

Mean of 15 replicates \pm s.e.

Row means with common superscripts do not differ $(\mathrm{P}>0.05)$.

AST $=$ aspartate aminotransferase; ALT $=$ alanine aminotransferase. 
is invaded by fungi during its development and harvest in the field, as well as during the process of transport and storage. Therefore, one of the factors affecting the sanitary quality of feeds prepared with this grain is aflatoxin contamination produced by certain species of fungi, among them strains of Aspergillus flavus. In this research, the aflatoxin quantification/identification method indicates that the toxins in the diet were only $\mathrm{AFB}_{2}$ and $\mathrm{AFB}_{1}$, with a total concentration of $39 \mathrm{ng} / \mathrm{g}$. These total aflatoxin concentration are commonly found in commercial grains of underdeveloped countries being one of the major causes of low productivity in animals. Animals which consume high levels of these toxins may develop various health problems, depending on their susceptibility. In the case of poultry, aflatoxicosis is characterized by weakness, anorexia with lower growth rate, poor utilization, decreased weight gain, decreased egg production, increased susceptibility to environmental/ microbial stress and increased mortality (Leeson et al 1995, Bailey et al 1998, Kubena et al 1998, Dershant-Li et al 2003, Kermanshahi et al 2009).

Supplementation with aqueous CA substantially reduced the $\mathrm{pH}$ of the diets according to the added content (table 2). This effect is interesting because the acidic treatment reduced the aflatoxin concentration in the feed up to $92 \%$. The chromatograms of acidified samples may provide support for detoxification activity. It also suggests that the molecule structure in post-treated aflatoxin contaminated samples changes, the lactone ring may be opened. Thus, detoxification initially involves the formation of the $\beta$-keto acid structure (catalyzed by de acidic medium), followed by hydrolysis of the lactone ring yielding the $\mathrm{AFD}_{1}$ molecule, derivated from decarboxylation of the lactone ring-opened form of $\mathrm{AFB}_{1}$ (Méndez-Albores et al 2005), which is 130 times less mutagenic in the Ames test and presenting 20-fold toxicity decrease (Schroeder et al 1985). Therefore, the fluorescence strength varies in the HPLC chromatograms at the same retention time values.

Organic acids are also extremely efficient against bacteria in poultry, and their antimicrobial effect increases with concentration/length of the carbon chain (Van Immerseel et al 2006). At a pH below 3.5, almost all organic acids are effective in controlling bacterial growth. As an alpha-hydroxy-carboxylic acid, CA has higher dissociation capacity and its carboxylic group links with ammonia in equimolar quantity (one molecule of CA saturated three molecules of ammonia), thus CA possesses inhibiting, bacteriostatic, and neutralizing effects against ammonifying bacteria, E. coli, and Salmonellae (Ivanov 2001).

Organic acids also have a positive effect on growth performance; since dietary acidification increases gastric proteolysis and protein/amino acid digestibility by enhancing digestive enzyme activities (Langhout 2000). The reason why protein is better used when CA is added to diet is due to the fact that pepsinogen is converted to pepsin, which increases pepsin activity and improves protein digestibility. Moreover, peptides arising from pepsin proteolysis trigger the release of hormones (including gastrin and cholecystokinin) which regulate the digestion and absorption of protein. The results of LBW, FC and FCR obtained in this experiment confirm those reported by Khosravi et al (2008) in broilers fed diet supplemented with $2 \mathrm{~g} / \mathrm{kg}$ propionic acid during $21 \mathrm{~d}$ period. In those birds, LBW, FC and FCR registered values of $612 \mathrm{~g}, 48 \mathrm{~g}$ and 1.5 , respectively. The improvement of FCR and the increase of LBW have already been demonstrated in broilers fed a diet supplemented with acidifiers (Denli et al 2003). However, test results for the inclusion of certain organic acids in broiler rations remain limited and controversial. Yesilbag and Colpan (2006) investigated the effect of three levels of an organic acid mixture (formic/propionic/ammonium salts) on performance, egg production/quality and serum parameters in laying hens. In general, growth performance (LBW and FC), and egg quality parameters were not significantly affected by supplementing diets with $0.5,1$ or $2 \%$ dietary organic acid mixture. Cave (1984) and Jacob et al (1990) reported a decrease in food consumption in broiler chickens fed with a diet containing 3\% and 7.5\% lactic acid, respectively. It is well known that organic acids have a low tendency to free their $\mathrm{H}^{+}$ions and the strong taste is associated with them. Consequently, high amounts of organic acid supplementation may reduce the feed consumption, because of changes in diet palatability. In this research, the highest addition of CA to diets $(50 \mathrm{~g} /$ $\mathrm{kg}$ ) was successfully tolerated by the chickens (table 3 ). In summary, the better LBW and FCR values in some acidified diets may be due to the effect of CA by reducing the aflatoxin content, or either by controlling pathogenic bacteria, or maintaining the health of GIT improving the broilers performance.

Among the different serum parameters measured, hematocrite, serum total protein, and albumin concentrations were not significantly affected at the end of the experiment in broilers receiving the four dosages of CA (table 4). These results are consistent with those obtained in broiler chicks due to acetic acid inclusion (Abdo 2004). Abdel-Fattah et al (2008) also reported that total protein and albumin were not affected due to the inclusion of 1.5 or $3 \% \mathrm{CA}$ in broiler chickens fed during $42 \mathrm{~d}$ period.

While the increment of the enzymatic values in birds varies with the different species, the elevation of the enzymatic activity has been correlated with hepatocellullar damage. The most frequent cause of the elevation of the AST activity in birds is hepatic disease; birds with AST values in the upper $230 \mathrm{U} / \mathrm{L}$ range are considered abnormal (Campbell and Coles 1986). A moderate increase (2-4 fold) in the AST enzyme is observed when there is soft weave injury, whereas in the hepatic necrosis, a more 
remarkable elevation is caused. In this research, the results demonstrate that the inclusion of different concentrations of CA in the feed, significantly affects the AST activity; however, the maximum increase in the AST activity (1.9 fold), was observed in birds fed a diet with $50 \mathrm{~g} \mathrm{CA} / \mathrm{kg}$ (table 4). In the case of ALT activity, lower values were registered due to the inclusion of $\mathrm{CA}$. These results are in agreement with those reported by Brenes et al (2003) who reported ALT values of 1 and 1.5 U/L in broiler chickens fed a diet containing $20 \mathrm{~g} \mathrm{CA} / \mathrm{kg}$ at different levels of available phosphorous (2.5 and $3.5 \mathrm{~g} / \mathrm{kg}$, respectively). Aktaç et al 2003a reported that CA $\left(\mathrm{LD}_{25}=480 \mathrm{mg} /\right.$ $\mathrm{kg} . \mathrm{bw})$ applied intraperitoneally to mice increases serum AST level (from 177.8 to $307.2 \mathrm{UI} / \mathrm{L}$ ), and decrease ALT activity (from 695 to $101 \mathrm{UI} / \mathrm{l}$ ). Microscopic examination of liver showed histopathological changes such as tissue degeneration, cytoplasmic vacuolisations, nuclear membrane invaginations, picnotic nucleus and necrosis of hepatocytes, in part attributed to acidosis and calcium deficiency. Those findings are in close agreement with the results found in the present investigation; however, the effect of CA on transaminase activity might be related to differences in gender and lines of the animals.

As shown in table 5, no statistical differences were noted among all treatments in the relative proventriculus, gizzard, liver, intestine, spleen and bursa percentages. These results confirmed those of Denli et al (2003) who found that dietary organic acids had no effect on carcass yield and liver weight of broiler chickens at $42 \mathrm{~d}$ old. Yesilbag and Colpan (2006) also concluded that dietary supplementation with organic acids did not affect interne organ weights (hearth, liver, and spleen) in laying hens fed with a diet containing up $1.5 \%$ organic acid mixture during 18 week period.

The effect of dietary acidification on $\mathrm{pH}$ values of different GIT segments are presented in table 6. The results indicate that $\mathrm{CA}$ supplementation slightly reduced proventriculus, gizzard, duodenum, jejunum and ileum $\mathrm{pH}$ values, compared with the control group. However, the differences are not significant. These results are consistent with Denli et al (2003) who reported that giving broilers an organic acid mixture showed no significant reduction in the intestinal pH. Hernández et al (2006) reported no effect on intestinal $\mathrm{pH}$ with the use of a product containing a combination of propionic/formic acid. These authors attributed this insignificant effect to the strong buffering action of the GIT in broiler chickens. Prior to birth, the GIT of birds is free of any strains of microbial populations, and bacteria from the diet, water, excreta and environment begin to colonize the GIT almost shortly.

Table 5. Effect of supplemental citric acid on some organs as a percentage of body weight in broiler chickens.

Efecto de la suplementación de ácido cítrico en algunos órganos expresado como porcentaje del peso corporal de los pollos de engorda.

\begin{tabular}{lccccc}
\hline \multirow{2}{*}{ Parameter } & \multicolumn{5}{c}{ Dietary organic acid supplementation $(\mathrm{g} \mathrm{CA} / \mathrm{kg})$} \\
\cline { 2 - 6 } & 6.25 & 12.5 & 25 & 50 & $0(\mathrm{control})$ \\
\hline Proventriculus & $0.5 \pm 0.03^{\mathrm{a}}$ & $0.5 \pm 0.01^{\mathrm{a}}$ & $0.6 \pm 0.05^{\mathrm{a}}$ & $0.5 \pm 0.02^{\mathrm{a}}$ & $0.6 \pm 0.01^{\mathrm{a}}$ \\
Gizzard & $2.4 \pm 0.10^{\mathrm{a}}$ & $2.3 \pm 0.18^{\mathrm{a}}$ & $2.4 \pm 0.14^{\mathrm{a}}$ & $2.4 \pm 0.08^{\mathrm{a}}$ & $2.5 \pm 0.27^{\mathrm{a}}$ \\
Liver & $2.8 \pm 0.19^{\mathrm{a}}$ & $2.9 \pm 0.14^{\mathrm{a}}$ & $2.5 \pm 0.21^{\mathrm{a}}$ & $2.5 \pm 0.17^{\mathrm{a}}$ & $2.9 \pm 0.15^{\mathrm{a}}$ \\
Intestine & $5.1 \pm 0.13^{\mathrm{a}}$ & $5.2 \pm 0.31^{\mathrm{a}}$ & $5.3 \pm 0.26^{\mathrm{a}}$ & $5.4 \pm 0.16^{\mathrm{a}}$ & $6.0 \pm 0.72^{\mathrm{a}}$ \\
Spleen & $0.08 \pm 0.01^{\mathrm{a}}$ & $0.12 \pm 0.03^{\mathrm{a}}$ & $0.08 \pm 0.01^{\mathrm{a}}$ & $0.09 \pm 0.01^{\mathrm{a}}$ & $0.10 \pm 0.01^{\mathrm{a}}$ \\
Bursa & $0.23 \pm 0.02^{\mathrm{a}}$ & $0.25 \pm 0.02^{\mathrm{a}}$ & $0.23 \pm 0.06^{\mathrm{a}}$ & $0.28 \pm 0.02^{\mathrm{a}}$ & $0.24 \pm 0.02^{\mathrm{a}}$ \\
\hline
\end{tabular}

Mean of 15 replicates \pm s.e.

Row means with common superscripts do not differ $(\mathrm{P}>0.05)$.

Table 6. Effect of supplemental citric acid on $\mathrm{pH}$ values of some gastrointestinal tract segments in broiler chickens.

Efecto de la suplementación de ácido cítrico en los valores de $\mathrm{pH}$ de algunos segmentos del tracto gastrointestinal de los pollos de engorda.

\begin{tabular}{lccccc}
\hline \multirow{2}{*}{ Parameter } & \multicolumn{5}{c}{ Dietary organic acid supplementation $(\mathrm{g} \mathrm{CA} / \mathrm{kg})$} \\
\cline { 2 - 6 } & 6.25 & 12.5 & 25 & 50 & $0(\mathrm{control})$ \\
\hline Proventriculus & $3.5 \pm 0.11^{\mathrm{a}}$ & $3.4 \pm 0.17^{\mathrm{a}}$ & $3.3 \pm 0.11^{\mathrm{a}}$ & $3.3 \pm 0.08^{\mathrm{a}}$ & $3.4 \pm 0.08^{\mathrm{a}}$ \\
Gizzard & $2.4 \pm 0.11^{\mathrm{a}}$ & $2.6 \pm 0.03^{\mathrm{a}}$ & $2.9 \pm 0.33^{\mathrm{a}}$ & $2.5 \pm 0.14^{\mathrm{a}}$ & $2.6 \pm 0.21^{\mathrm{a}}$ \\
Duodenum & $6.2 \pm 0.04^{\mathrm{a}}$ & $6.1 \pm 0.12^{\mathrm{a}}$ & $6.1 \pm 0.08^{\mathrm{a}}$ & $6.4 \pm 0.06^{\mathrm{a}}$ & $6.3 \pm 0.05^{\mathrm{a}}$ \\
Jejunum & $6.3 \pm 0.04^{\mathrm{a}}$ & $6.4 \pm 0.06^{\mathrm{a}}$ & $6.3 \pm 0.03^{\mathrm{a}}$ & $6.4 \pm 0.04^{\mathrm{a}}$ & $6.4 \pm 0.01^{\mathrm{a}}$ \\
Ileum & $6.6 \pm 0.10^{\mathrm{a}}$ & $6.5 \pm 0.11^{\mathrm{a}}$ & $6.4 \pm 0.03^{\mathrm{a}}$ & $6.6 \pm 0.06^{\mathrm{a}}$ & $6.5 \pm 0.10^{\mathrm{a}}$ \\
\hline
\end{tabular}

Mean of 15 replicates \pm s.e.

Row means with common superscripts do not differ $(\mathrm{P}>0.05)$. 
Consequently, the $\mathrm{pH}$ level in specific areas of the GIT is a factor which establishes a specific microbial population, and also affects the digestibility and absorption of most nutrients. Taking into account that most pathogens grow at a $\mathrm{pH}$ close to 7 , and that beneficial microorganisms live in an acidic media (5.8-6.2) in which they compete with pathogens, CA could be used as an alternative for immune system development as well as for increasing bird performance.

In conclusion, the current study showed that the aqueous CA treatment significantly reduce the aflatoxin content in the ration. CA supplementation also promotes growth performance of young broiler chickens; however, CA increases serum AST levels and decrease ALT activity. According to these results, it seems that CA may be beneficial when used in broilers chickens. Nevertheless, further studies are needed on the effect of these organic acid concentrations on the complete broiler growing cycle.

\section{SUMMARY}

This study was undertaken to investigate the effects of citric acid (CA) on aflatoxin degradation, growth performance and some serum constituents in broilers. 300 one-day-old Ross broiler chickens were randomly divided into five treatment groups of three replicates, 20 chicks each. Four groups received the diet supplemented with CA $(6.25,12.5$, 25 and $50 \mathrm{~g} / \mathrm{kg}$ ), while the other served as a control. Diet was prepared following the NRC guidelines and the experiment was terminated when chicks were $28 \mathrm{~d}$ old. The results showed that aflatoxins in the diet, at a concentration of $39 \mathrm{ng} / \mathrm{g}$ were almost degraded (92\%) by the acidification procedure. In general, live body weight (LBW) was slightly higher in animals fed with the addition of CA; diet containing the highest concentration $(50 \mathrm{~g} \mathrm{CA} / \mathrm{kg})$ resulted in a significant increase in LBW and improvement of feed conversion ratio. However, as the CA concentration increased, higher serum aspartate aminotransferase activity values were registered. On the contrary, hematocrite, total protein and albumin were not affected by any level of added CA. From these results, it is concluded that dietary CA supplementation can be used as an additive to degrade aflatoxins in the ration as well as to promote growth performance in young broiler chickens.

\section{ACKNOWLEDGEMENTS}

The authors would like to thank CONACYT for their financial support.

\section{REFERENCES}

AACC. 2000. Approved Methods of the American Association of Cereal Chemists. $10^{\text {th }}$ ed. Method 02-52. The Association, St. Paul, MN, USA.

Abd-AlGadir MI, MM Ihaimer, MK Sabah-Elkhier, OF Idris. 2009. Effect of benzoic acid and combination of benzoic with citric acid as food additives on the renal function of experimental rats. Asian $J$ Clin Nutr 1, 83-87.

Abdel-Fattah SA, MH El-Sanhoury, NM El-Mednay, F Abdel-Azeem. 2008. Thyroid activity, some blood constituents, organs morphology and performance of broiler chicks fed supplemental organic acids. Int J Poult Sci 7, 215-222.

Abdo MAZ. 2004. Efficacy of acetic acid in improving the utilization of low protein-low energy broiler diets. Egypt Poult Sci 24, 123-141.

Aktaç T, A Kaboğlu, E Bakar, H Karacas. 2003a. The short-term effects of single toxic dose of citric acid in mice. J Cell Mol Biol 2, 19-23.
Aktaç T, A Kaboğlu, F Ertan, F Ekinci, G Huseyinova. 2003 ${ }^{\text {b. The }}$ effects of citric acid [antioxidant] and benzoic acid [antimicrobial agent] on the mouse liver: biochemical and histopatological study. Biologia Bratisl 58, 343-347.

AOAC, 1995. Association of Official Analytical Chemists, Official Methods of Analysis. 16 ${ }^{\text {th }}$ ed. Method 991.31. Gaithersburg, MD, USA.

Bailey RH, LF Kubena, RB Harvey, SA Buckley, GE Rottinghaus. 1998. Efficacy of various inorganic sorbents to reduce the toxicity of aflatoxin and T-2 toxin in broiler chickens. Poult Sci 77, 1630-1632.

Brenes A, A Viveros, I Arija, C Centeno, M Pizarro, C Bravo. 2003. The effect of citric acid and microbial phytase on mineral utilization in broilers chicks. Anim Feed Sci Technol 110, 201-219.

Cave NAG. 1984. Effect of dietary propionic and lactic acid on feed intake by chicks. Poult Sci 63, 131-134.

Charmley LL, HL Trenholm, DB Preluski. 1995. Mycotoxins: their origin, impact and importance: insights into common methods of control and elimination. In: Lyons TP, Jacques KA (eds). Biotechnology in the feed industry: Proceedings of Alltech's Eleventh Annual Symposium. Nottingham University Press, Nottingham, UK, Pp 41-63.

Chaveerach P, DA Keuzenkamp, LJ Lipman, F Van Knapen. 2004. Effect of organic acids in drinking water for young broilers on Campylobacter infection, volatile fatty acid production, gut microflora and histological cell changes. Poult Sci 83, 330-334.

Coenen A, A Smit, L Zhonghua, G Van Luijtelaar. 2000. Gas mixtures for anaesthesia and euthanasia in broiler chickens. World's Poult Sci J 56, 226-234.

Campbell TW, EH Coles. 1986. Avian clinical pathology. In: Coles EH (ed). Veterinary clinical pathology. $4^{\text {th }}$ ed. WB Saunders Company, Philadelphia, USA, Pp 279-291.

Denli M, F Okan, K Celik. 2003. Effect of dietary probiotic, organic acid and antibiotic supplementation to diets on broiler performance and carcass yield. Pak J Nutr 2, 89-91.

Dershant-Li Y, MWA Verstegen, WJJ Gerrits. 2003. The impact of low concentration of aflatoxin, deoxynivalenol or fumonisin in diets on growing pigs and poultry. Nutr Res Rev 16, 223-239.

Dowling TS. 1997. Fumonisins and its toxic effects. Cereal Foods World 42, 13-15.

Feibelman TP, PJ Cotty, MA Doster, TJ Michailides. 1998. A morphologically distinct strain of Aspergillus nomius. Mycologia 90, 618-623.

Hansen JT. 1990. Affinity column clean-up and direct fluorescence measurement of aflatoxin $\mathrm{M}_{1}$ on raw milk. J Food Protect 53, 75-77.

Hernández F, V García, J Madrid, J Orengo, P Catalá, MD Megias. 2006. Effect of formic acid on performance, digestibility, intestinal histomorphology and plasma metabolite levels of broiler chickens. Br Poult Sci 47, 50-56.

Hussein HS, JM Brasel. 2001. Toxicity, metabolism and impact of mycotoxins on humans and animals. Toxicol 167, 101-134.

ICRISAT/FAO, 1996. International Crops Research Institute for the Semi-Arid Tropics/Food and Agriculture Organization. The world sorghum and millet economies. ICRISAT, Patancheru, India/FAO, Rome.

Ivanov IE. 2001. Treatment of broiler litter with organic acids. Res Vet Sci 70, 169-173.

Jacob JP, R Blair, EE Gardiner. 1990. Effects of dietary lactate and glucose on the incidence of sudden death syndrome in male broiler chickens. Poult Sci 69, 1529-1532.

Jin LZ, YW Ho, N Abdullah, S Jalaludin. 1998. Growth performance, intestinal microbial populations, and serum cholesterol of broilers fed diets containing Lactobacillus cultures. Poult Sci 77, 12591265 .

Kermanshahi H, MR Akbari, M Maleki, M Behgar. 2007. Effect of prolonged low level inclusion of aflatoxin $B_{1}$ into diet on performance, nutrient digestibility, histopathology, and blood enzymes of broiler chickens. J Anim Vet Adv 6, 686-692. 
Kermanshahi H, AR Hazegh, N Afzali. 2009. Effect of sodium bentonite in broiler chickens fed diets contaminated with aflatoxin $\mathrm{B}_{1} . J$ Anim Vet Adv 8, 1631-1636.

Khosravi A, F Bolají, B Dastar, S Hasani. 2008. The use of some feed additives as growth promoter in broilers nutrition. Int J Poult Sci 7, 1095-1099.

Kristiansen B, J Linden, M Mattey. 1999. Citric Acid Biotechnology. Taylor \& Francis Ltd., London, UK, Pp 7-9.

Kubena LF, RB Harvey, RH Bailey, SA Buckley, GE Rottinghaus. 1998. Effects of hydrated sodium calcium aluminosilicate $\left(\mathrm{T}-\mathrm{Bin}^{\mathrm{TM}}\right)$ in mycotoxicosis in young broiler chickens. Poult Sci 77, 1502-1509.

Langhout P. 2000. New additives for broiler chickens. World PoultryElsevier 16, 22-27.

Leeson S, G Diaz, JD Summers. 1995. Poultry metabolic disorders and mycotoxins. University Books, Guelph, Ontario, Canada, Pp 249-298.

Méndez-Albores A, G Arámbula-Villa, MGF Loarca-Piña, E CastañoTostado, E Moreno-Martínez. 2005. Safety and efficacy evaluation of aqueous citric acid to degrade B-aflatoxins in maize. Food Chem Toxicol 43, 233-238.

Méndez-Albores A, JC Del Río-García, E Moreno-Martínez. 2007. Decontamination of aflatoxin duckling feed with aqueous citric acid treatment. Anim Feed Sci Technol 135, 249-262.

Méndez-Albores A, J Veles-Medina, E Urbina-Álvarez, F MartínezBustos, E Moreno-Martínez. 2009. Effect of citric acid on aflatoxin degradation and on functional and textural properties of extruded sorghum. Anim Feed Sci Technol 150, 316-329.
Naidu AS. 2000. Natural food antimicrobial systems.CRC Press, USA, Pp 431-462.

NRC. 1994. Nutrient requirement of poultry. $9^{\text {th }}$ ed. National Academy Press, Washington, DC, USA.

Reitman S, S Franked. 1970. Transaminase GOT and GPT. In: Willard RF, John WK (eds). CRC Manual of Clinical Laboratory Procedures. The Chemical Rubber Co, Cleveland, USA, Pp 84-85.

Runho RC, NK Sakomura, S Kuana, D Banzatto, OM Junqueira, JH Stringhini. 1997. Use of an organic acid (fumaric acid) in broiler rations. R Bras Zootec 26, 1183-1191.

SAS. 1998. Introductory Guide for Personal Computers. SAS Institute 6.12 ed. Cary, NC, USA.

Schroeder T, U Zweifel, P Sagelsdorff, U Friederich, J Luthy, C Schlatter. 1985. Ammoniation of aflatoxin-containing corn: distribution, in vitro covalent deoxyribonucleic acid binding, and mutagenicity of reaction products. J Agric Food Chem 33, 311-316.

Van Immerseel F, JB Russell, MD Flythe, I Gantois, L Timbermont, F Pasmans, F Haesebrouck, R Ducatelle. 2006. The use of organic acids to combat Salmonella in poultry: a mechanistic explanation of the efficacy. Avian Pathol 35, 182-188.

Weidenbörner M. 2007. Mycotoxins in Feedstuffs. Springer-Verlag, New York Inc, USA.

Yesilbag D, I Colpan. 2006. Effects of organic acid supplemented diets on growth performance, egg production and quality and on serum parameters in laying hens. Revue Méd Vét 157, 280-284.

Yılmaz I, F Ünal, D Yüzbaşığlu, H Aksoy. 2008. Clastogenic effects of food additive citric acid in human peripheral lymphocytes. Cytotechnology 56, 137-144. 